\title{
Tidal-current transport of thread-drifting postlarval juveniles of the bivalve Macoma balthica from the Wadden Sea to the North Sea
}

\author{
J. J. Beukema, J. de Vlas \\ Netherlands Institute for Sea Research, PO Box 59, 1790 AB Den Burg, Texel, The Netherlands
}

\begin{abstract}
Laboratory experiments were carried out on thread-bearing spat of the tellinid bivalve Macoma balthica, and in the field high numbers of these juveniles (of up to $1 \mathrm{~cm}$ shell length) were caught in winter in plankton nets suspended in tidal streams of the Wadden Sea (The Netherlands). These data are used to explain the distribution and dynamics of a population of the species in the North Sea off the West-Frisian island Terschelling. Evidence is presented that nearly all $M$. balthica arrive in this area in winter by secondary settlement after tidal current transport, facilitated by long hyaline threads. $M$. balthica were numerous only close to a tidal inlet connecting the area with the Wadden Sea. Further away (more than 10 to $15 \mathrm{~km}$ ), young $M$. balthica arrived in low numbers only and were smaller. All or nearly all $M$. balthica in the North Sea will have originated from massive primary settlement of just-metamorphosed larvae more than half a year previously (in spring and summer) on high tidal flats in the Wadden Sea. Some functional aspects of dispersal by secondary settlement are discussed.
\end{abstract}

\section{INTRODUCTION}

Dispersal in several species of bivalves appears to take place during 2 separate periods of pelagic existence: an initial larval phase before first settlement to the bottom and a second phase after a more or less prolonged benthic period. Transport during secondary dispersal of the much bigger postlarvae (spat of a few $\mathrm{mm}$ length) is facilitated by a long thread that increases viscous drag, thus enabling the young bivalves to be carried along on relatively weak currents (Sigurdsson et al. 1976, Lane et al. 1985, Yankson 1986). Such threads appear to be a common feature in marine molluscs (Sigurdsson et al. 1976) and have also been described in at least one freshwater species (Prezant \& Chalermwat 1984). Postmetamorphic stages (generally up to 10 or $15 \mathrm{~mm}$ size) of several species of bivalves have been reported to occur in the meroplankton (Williams \& Porter 1971).

Enhanced transport by thread drifting will result in long-distance dispersal and might enable the bivalves to settle, at a later time and with greater size, away from the areas suitable for small just-metamorphosed larvae. So far, few reports are avallable on the importance of such a transport for population dynamics and for the enlargement of the area of distribution. The case of the mussel Mytilus edulis L. is however well known: primary settlement on filamentous substrata and secondary settlement on hard substrates such as mussel beds or rocks (Bayne 1964). Cockles Cerastoderma edule (L.) were found to be transported for a considerable time after metamorphosis until they had reached a size of about $2 \mathrm{~mm}$, when they accumulated in quiet places (Baggerman 1953).

Primary settlement of Macoma balthica (L.) larvae on tidal flats in the Wadden Sea occurs mostly in late spring after spawning in April or May. High densities (up to thousands per $\mathrm{m}^{2}$ ) of small spat can be found throughout summer on relatively high tidal flats (well above MTL) where sediments are fine-grained and relatively silty. The mean length of spat increases during summer from about $0.2 \mathrm{~mm}$ to about $5 \mathrm{~mm}$. In winter, spat numbers were found to decline rapidly in these areas (Fig. 6b of Beukema et al. 1978), whereas they increased in other areas, including low and exposed tidal flats (Fig. 6a of ibid.). Migration was an 
obvious explanation (Beukema 1973), but at that time the mechanism was not understood. Later, we observed that small $M$. balthica could posses almost invisible hyaline mucous threads. These threads can be picked up and made visible by pulling them cautiously above the water surface. Any touching of the shell immediately causes the thread to break off. This easy loss and the transparency of the threads explains why these threads were not previously observed in the field.

Using passive plankton nets, de Vlas (1973) caught huge numbers of Macoma balthica spat in tidal channels and around an inlet of the western Wadden Sea during winter and early spring. In April. Swennen (1955) directly observed 5 to $12 \mathrm{~mm}$ long $M$. balthica floating in the water at high tide over a tidal flat in the Wadden Sea.

These observations are easily explained by thread drifting. Roughly half of the water in the Wadden Sea flows to the North Sea during ebb, creating tidal currents that could transport the spat over long distances. This paper will present evidence for the actual existence of such a large-scale migration resulting in true dispersal.

\section{METHODS}

Laboratory experiments. Sinking speeds of Macoma balthica with and without threads were measured in a transparent $120 \mathrm{~cm}$ long vertical tube, filled with cold $\left(5\right.$ to $10^{\circ} \mathrm{C}$ ) seawater. The experiments were described in detail by Den Dulk \& Van der Velde (1987). Briefly, gently stirring the water stimulated juveniles of $M$. balthica of known shell length (range: 2 to $9 \mathrm{~mm}$ ) to form a thread in a compartment around the top of the tube. Once a thread appeared, it was picked up by a glass rod and moved cautiously to the centre of the tube top. The distance between the shell and the rod at the moment of (spontaneous or forced) detachment from the rod was measured and used as an estimate of the length of the thread. Subsequently, the time to sink $1 \mathrm{~m}$ was measured. Specimens sinking with a thread moved slowly and in a vertical top-down position. Specimens without a thread (or after occasional loss of their thread) sank in a characteristic fluttering way. Care was taken to avoid any turbulence or air bubbles in the water, because even slight movements or a few bubbles attached to the thread reduced the sinking speed or even reversed the downward movement.

Tidal current transport. Macoma balthica suspended in the water were sampled by a circular plankton net (ca $10 \mathrm{~m}$ length, $1 \mathrm{~m}^{2}$ opening, mesh $1 \mathrm{~mm}$ ). Fishing was either passive or active. For passive fishing the net was lowered from an anchored vessel and kept for either 10 or 20 min at a depth halfway between bottom and surface. Simultaneous fishing trials at various depths (de Vlas 1973) showed that catches increased from the surface to the bottom and that catches at middepth were representative of the whole water column. The mouth of the net was kept in a vertical position by a heavy weight and a float on a rope of variable length. Passive fishing was done only when current speeds exceeded ca $0.5 \mathrm{~m} \mathrm{~s}^{-1}$ (i.e. 4 to $5 \mathrm{~h}$ out of the ca $6 \mathrm{~h}$ of the ebb or flood period). Active fishing could be done at all stages of the tide by towing the net for periods of 10 min at a constant speed of ca $0.5 \mathrm{~m} \mathrm{~s}^{-1}$ at a depth half-way between the bottom and the surface. During all fishing periods (and also during the anchoring periods alternating with active fishing), current speed was measured by means of a Savonin rotor kept at the same depth as the mouth of the net. Passive fishing was executed during 60 tides (about 500 hauls) almost yearround in 1970-71 in the Marsdiep area between Texel and Den Helder (Fig. 1). Active fishing was executed on 9 and 10 January 1974 along a $500 \mathrm{~m}$ transect in the longitudinal axis of the Zoutkamperlaag, a tidal inlet near Schiermonnikoog (Fig. 1a). This transect was fished 21 times for 10 min over 2 full ebb periods ( 1 or 2 hauls per hour).

The contents of the net were washed to the cod end and subsequently into a container with seawater. Invariably, all Macoma balthica sank rapidly to the bottom of the container and could easily be separated by repeated decanting from most other material caught. They were counted and their shell lengths (and year marks, if present) were measured to the nearest $0.5 \mathrm{~mm}$.

Passive fishing time generally amounted to ca 10 times 10 or 20 min or up to ca 3.5 h per tidal period of ca $6 \mathrm{~h}$, alternating with short periods for hauling and washing the net. The total number passing through $1 \mathrm{~m}^{2}$ during a total tidal period was estimated by interpolation. The small numbers passing at low current speeds around the turns of the tide were neglected.

Field distribution. The distribution pattern of the bottom-dwelling Macoma balthica in the North Sea off the island of Terschelling (Fig. 1a) was studied in an area of ca $100 \mathrm{~km}^{2}$ between $53^{\circ} 25^{\prime}$ and $53^{\circ} 30^{\prime} \mathrm{N}$ and between $5^{\circ} 15^{\prime}$ and $5^{\circ} 35^{\prime} \mathrm{E}$. Within this area, samples were taken at 17 fixed stations located by Decca navigation (within ca $100 \mathrm{~m}$ or better). Stations were located up to $6 \mathrm{~km}$ from the beach at depths between 7 and $18 \mathrm{~m}$. Sediments were sandy (median grain size 130 to $170 \mu \mathrm{m})$ with low percentages $(0.1$ to 4.7$)$ of material smaller than $50 \mu \mathrm{m}$. The area was surveyed in spring (late April to early June) on 9 occasions between 1973 and 1982. Additional surveys were made in winter (January to early February) during 5 yr between 1973 and 1978 and once in autumn (September 1972). During each survey, 10 samples were taken at each station 


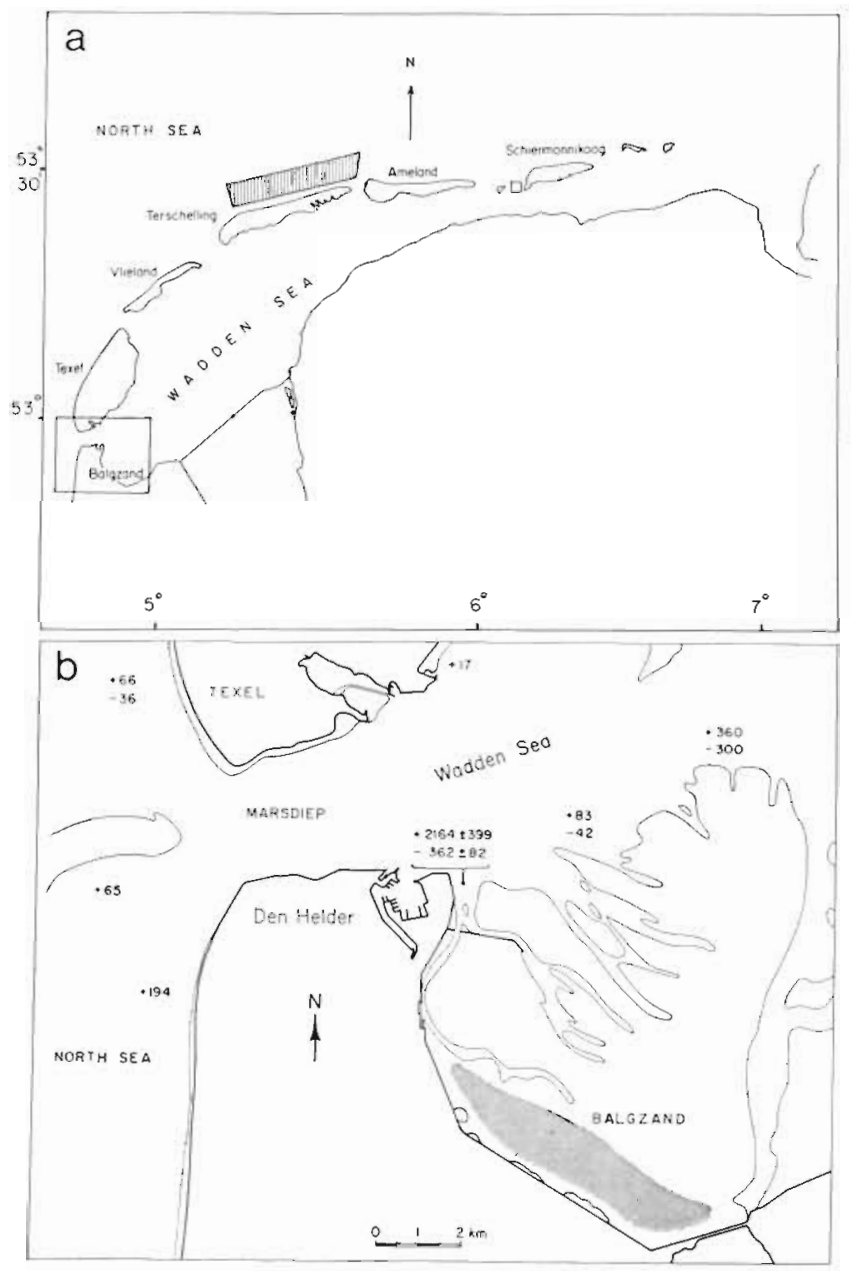

Fig. 1. (a) Western part of the Wadden Sea indicating locations of sampling areas for passive fishing (between Texel and the mainland), bottom sampling (at Balgzand and off Terschelling) and active fishing (west of Schiermonnikoog). (b) Estimated numbers of Macoma balthica spat (1970 year class) passing per tide $(+=$ ebb tides; $-=$ flood tides) through a vertical $1 \mathrm{~m}^{2}$ at various stations in the Marsdiep area in February-March 1971 (detailed data in De Vlas 1973). The main tidal stream draining Balgzand was fished during 11 ebb tides and 8 flood tides in this period and values for this station are shown \pm 1 standard error (other stations were mostly fished for 1 or 2 tides only). Shaded area shows high spat densities in summer

by means of a $0.2 \mathrm{~m}^{2}$ Van Veen grab. Beukema (1974a) showed this grab to be suitable for sampling $M$. balthica quantitatively. The grab penetrated 5 to $10 \mathrm{~cm}$ into the bottom (the few samples of less than $10 \mathrm{dm}^{3}$ sediment were discarded). To save time, the 10 grab samples were lumped to one station sample of $2 \mathrm{~m}^{2}$, sieved ( $1 \mathrm{~mm}$ mesh size) on board and frozen, to be sorted in the laboratory. $M$. balthica were sorted according to age class (up to age ca 6 yr) by counting the annual growth marks. Individuals of spat size were measured as in the net samples.

\section{RESULTS}

\section{Laboratory experiments}

Sinking rate of Macoma balthica spat was directly proportional to shell length and inversely proportional to thread length (Fig. 2). Thread lengths up to 100 times shell lengths were noted in the smallest spat and up to 30 times in the largest. In particular when threads were

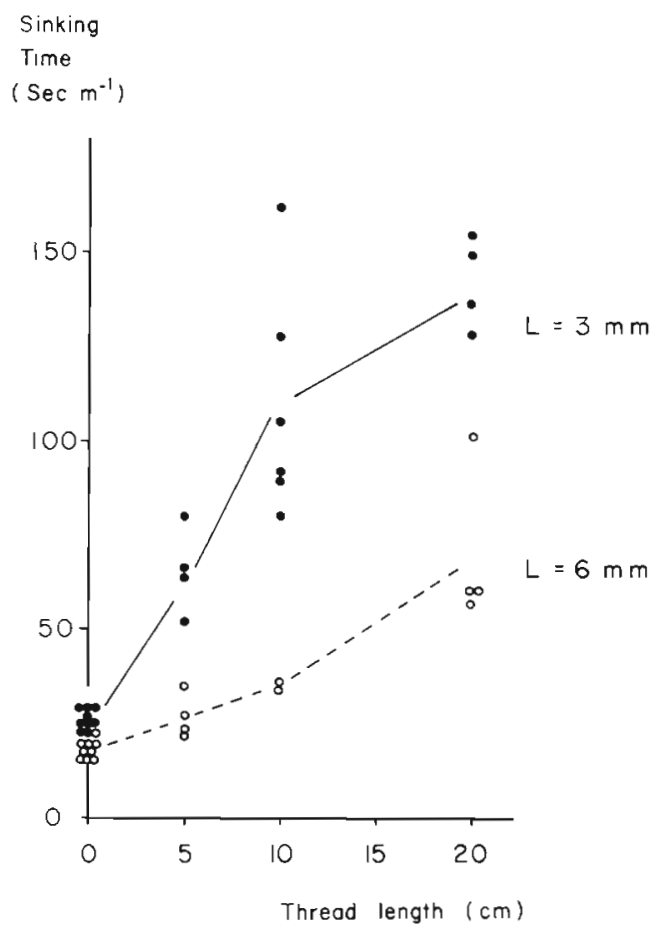

Fig. 2. Macoma balthica. Time (s) to sink $1 \mathrm{~m}$ in quiet water; spat of 2 size classes ( $3 \mathrm{~mm} ; 0: 6 \mathrm{~mm}$ shell length) and with different thread lengths (ca 5,10 and $20 \mathrm{~cm}$ )

long, sinking times could be prolonged (several min) and become very long (tens of min) in slightly turbulent water. In a more natural situation (turbulent water, no nearby walls or other obstacles), small $M$. balthica with long threads would remain in motion between the bottom and surface for long periods, perhaps hours. The sinking speeds shown in Fig. 2 would only apply during the periods of (nearly) still water at the turn of the tides. Once an individual was touched, it lost its thread. Thus all individuals tested immediately after capture rapidly sank.

\section{Characteristics of tidal-current transport}

Passive fishing was frequently executed in the main tidal channel that drains Balgzand (a $50 \mathrm{~km}^{2}$ tidal-flat area) near where it joins Marsdiep, the main draining 
channel of the western Wadden Sea (Fig. 1). During the 8 mo period October 1970 to May 1971, juveniles of the 1970 year class of Macoma balthica were sampled during 2 to 10 tidal periods per month (with about 10 hauls per tidal period). Catches during ebb tides were invariably higher than those during flood tides of the same or nearest date (Fig. 3), indicating that ca 10 times

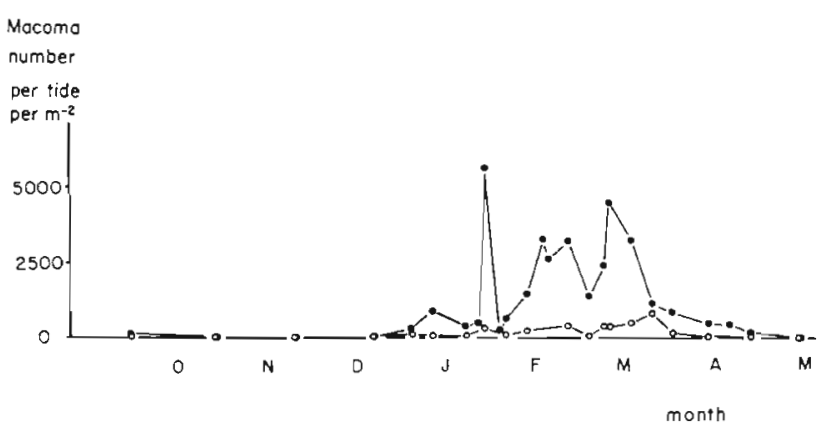

Fig. 3. Macoma balthica. Estimated numbers spat (1970 year class) passing per tide ( $\bullet$ : ebb tides; 0 : flood tides) the vertical $1 \mathrm{~m}^{2}$ aperture of a plankton net suspended at a station in the main stream draining Balgzand (see Fig. 1b) on various dates between October 1970 and May 1971 (adapted from de Vlas 1973)

more juveniles were leaving the Balgzand area than returning to it through this channel. Migration was particularly strong during late winter (February and March).

The numbers of spat leaving Balgzand in the course of a winter season can be estimated. During winter, the average number of spat that passed per $\mathrm{m}^{2}$ of the channel profile per ebb tide was a few thousands higher than the number returning at flood (Fig. 3). As the channel has a cross-sectional area of ca $1000 \mathrm{~m}^{2}$. the number of juvenile Macoma balthica exported from Balgzand will have amounted to a few million per tide or some hundreds of millions during the winter.

The emigrating spat will for the greater part have originated from the southern part of Balgzand where high densities (hundreds or thousands per $\mathrm{m}^{2}$ ) can be found in summer and autumn. In 1970, roughly 1000 million were present in August (for sampling method, see Beukema 1974b). Thus a significant proportion of this spat population (about $20 \%$ of the summer population, but probably a higher proportion of the winter population of spat) will have left the area by tidalcurrent transport. Only a few percent of the spat population were found to be still present at the higher parts of the tidal flats at an age of 1 yr.

Passive fishing in other tidal channels in the Marsdiep area revealed generally lower numbers passing per tide through a vertical $\mathrm{m}^{2}$ (Fig. $1 \mathrm{~b}$ ). This was to be expected, because the southern Balgzand area is by far the most important area of primary spat-fall in the
Marsdiep tidal basin. The spat concentrations of the Balgzand draining channel are thus diluted by the huge water masses passing the Marsdiep tidal inlet. Multiplication of the cross-sectional areas of the large channels around the inlet by the respective numbers shown in Fig. 1b yields a total mean estimate of ca 10 million spat present simultaneously in the water of the Marsdiep tidal basin in winter. This number is several times higher than the daily emigration from Balgzand. As there are (apart from Balgzand) no other major spatproducing areas within immediate reach of the Marsdiep tidal inlet, the juveniles appear to remain in the water of the tidal streams for some tides in succession. Consequently, they may have been transported over distances of several $\mathrm{km}$ or even some tens of $\mathrm{km}$. Note that the numbers caught during ebb tides always exceeded those of the flood tides (Fig. 1b), i.e. net transport was in a seaward (westward) direction.

The above results were obtained by passive fishing. This means that the catches were highly dependent on the actual current speeds. It is unknown whether the net fished with the same efficiency at all speeds. The numbers passing may have been underestimated at high speeds by clogging, causing lower current speeds in the mouth of the net than around the net. More reliable data on the concentrations $\left(\right.$ no. $\mathrm{m}^{-3}$ ), instead of numbers passing through a vertical $\mathrm{m}^{2}$, were obtained by active fishing.

Numbers of spat caught per 10 min of active fishing, during which ca $300 \mathrm{~m}^{3}$ water was filtered, again varied strongly (Fig. 4b) with the state of the tide (Fig. 4a). Maximum numbers were caught towards the end of the ebb tide (in passive fishing the maxima occurred earlier, closer to the maximum of the current speed). During the turns of the tide the spat concentrations were low (Fig. 4b). At very low current speeds, the juveniles apparently disappeared from the water column by sinking, as one would expect if they are threaddrifting. Moreover the expectation (from Fig. 2) that larger spat disappear more quickly from the water column than small spat during periods of low current speed around the turn of the tide is corroborated (Fig. $4 \mathrm{c})$. The mean length of the last 21 individuals caught (ca $6 \mathrm{~h}$ after HW, at current speeds less than one tenth of the maximal; Fig. 4a) was significantly lower $(p<0.01$, Student's t-test with $n=21$ and 12 to 28$)$ than all 6 other values for mean length (Fig. 4c). Thus small spat will stay longer in the water column and will be transported over longer distances than large spat.

\section{Distribution of Macoma balthica in the North Sea}

If the Macoma balthica population living off the Frisian Islands in the North Sea results primarily from 

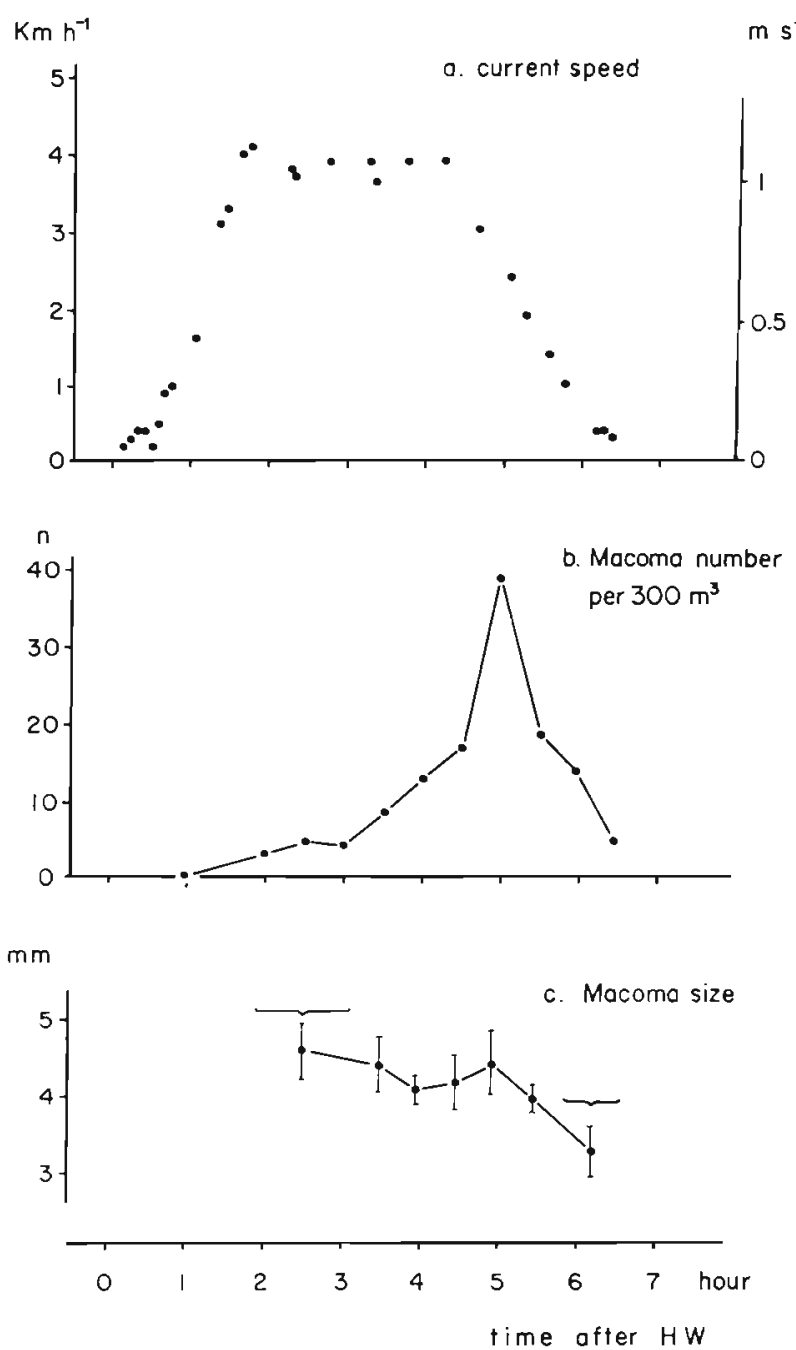

Fig. 4. Changes observed during an ebb tide in a major tidal stream (Zoutkamperlaag near Schiermonnikoog, see Fig. 1a). (a) Current speeds measured while anchored between fishing periods (data for 10 January 1974), expressed both in $\mathrm{km} \mathrm{h}^{-1}$ (left hand axis) and in $\mathrm{m} \mathrm{s}$ (right hand axis). (b) Numbers of Macoma balthica spat (1973 year class) caught by towing a $1 \mathrm{~m}^{2}$ plankton net for ca $10 \mathrm{~min}$ at ca $1 \mathrm{knot}\left(\cong 0.5 \mathrm{~m} \mathrm{~s}^{-1}\right)$. Numbers shown are slightly corrected to account for numbers present in $300 \mathrm{~m}^{3}$ water. Means of 2 ebb tides $(9$ and 10 January 1974). (c) Mean shell lengths ( \pm 1 standard error) of M. balthica spat caught during various fishing periods on 10 January 1974 (length data from catches of less than 10 individuals were combined)

migrants from Wadden Sea populations, some predictions can be made on the basis of the above results: (1) spat numbers on the North Sea bottom will increase in winter (as contrasted to the normal recruitment period in spring and summer); (2) these numbers will be particularly high near tidal inlets between the islands and decrease with increasing distances from these inlets; (3) with increasing distance from the inlets the mean size of the spat will decrease.
These predictions were tested by repeatedly sampling a grid of 17 stations in an area off Terschelling (Fig, 1a). The distances between these stations and the centre of the tidal inlet between Terschelling and Ameland varied from $\mathrm{ca} 7$ to ca $24 \mathrm{~km}$. Ebb currents in this area flow westwards

During the 3 or 4 mo between the sampling in January-February and that in the same year in May-June, the numbers of spat invariably increased significantly (Table 1), whereas the numbers of adults decreased (in

Table 1. Macoma balthica. Changes in mean numbers per $\mathrm{m}^{2}$ of 2 age groups in $2 \mathrm{~m}^{2}$ bottom samples taken in the North Sea off Terschelling (see Fig. 1a). Juveniles were ca 1 yr old at sampling and adults $>1$ yr. Statistical significance shown by $\cdot p<0.05, \cdots p<0.01$ as evaluated by the Mann-Whitney $U$-test ( $n$ : number of stations)

\begin{tabular}{|c|c|c|c|c|c|c|c|}
\hline \multirow[t]{2}{*}{ Year } & \multirow[t]{2}{*}{$n$} & \multicolumn{3}{|c|}{ Juveniles } & \multicolumn{3}{|c|}{ Adults } \\
\hline & & Sep & $\begin{array}{c}\text { Jan/ } \\
\text { Feb }\end{array}$ & $\begin{array}{c}\text { May/ } \\
\text { Jun }\end{array}$ & Sep & $\begin{array}{c}\text { Jan/ } \\
\text { Feb }\end{array}$ & $\begin{array}{c}\text { May/ } \\
\text { Jun }\end{array}$ \\
\hline \multirow{3}{*}{$\begin{array}{l}1972- \\
1973\end{array}$} & 7 & 5 & 12 & & $99^{\circ}$ & 66 & \\
\hline & 11 & & 10 & 38 & & 61 & $\because 40$ \\
\hline & 13 & 3 & & $\because 21$ & 58 & & · 26 \\
\hline 1974 & 17 & & 25 & - $\quad 51$ & & 29 & 32 \\
\hline 1975 & 17 & & 2 & $\cdots 32$ & & 61 & - 39 \\
\hline 1977 & 16 & & 2 & $\cdots 36$ & & 27 & 20 \\
\hline 1978 & 17 & & 18 & $\cdots 49$ & & 33 & - 24 \\
\hline
\end{tabular}

most years significantly, $p<0.05$, Wilcoxon signedranks test). In 1972, samples were also taken in September. The numbers of spat were still low off Terschelling at that time, when near to maximum numbers are recorded on the tidal flats in the Wadden Sea. By May 1973, numbers of spat of the 1972 year class had increased significantly off Terschelling (Table 1), but had dramatically decreased on the coastal tidal flats (compare Fig. 6b of Beukema et al. 1978). Thus, by far the greater part of the 1972 year class present in May 1973 off Terschelling was still absent in autumn 1972 and therefore must have arrived during the winter. These late-arriving spat will have been migrants which grew to a size of several $\mathrm{mm}$ elsewhere, probably on the high tidal flats in the nearby Wadden Sea compartment.

The mean densities of roughly 1 -yr-old juveniles observed in May and June in bottom samples taken off Terschelling were higher at stations close to the tidal inlet than further away from this connection with the Wadden Sea. The same holds for older Macoma balthica (Fig. 5). In both cases the negative correlation between distance and mean density was statistically significant $(p<0.01$, Spearman rank test, $r=-0.86$ and -0.71 , respectively). 


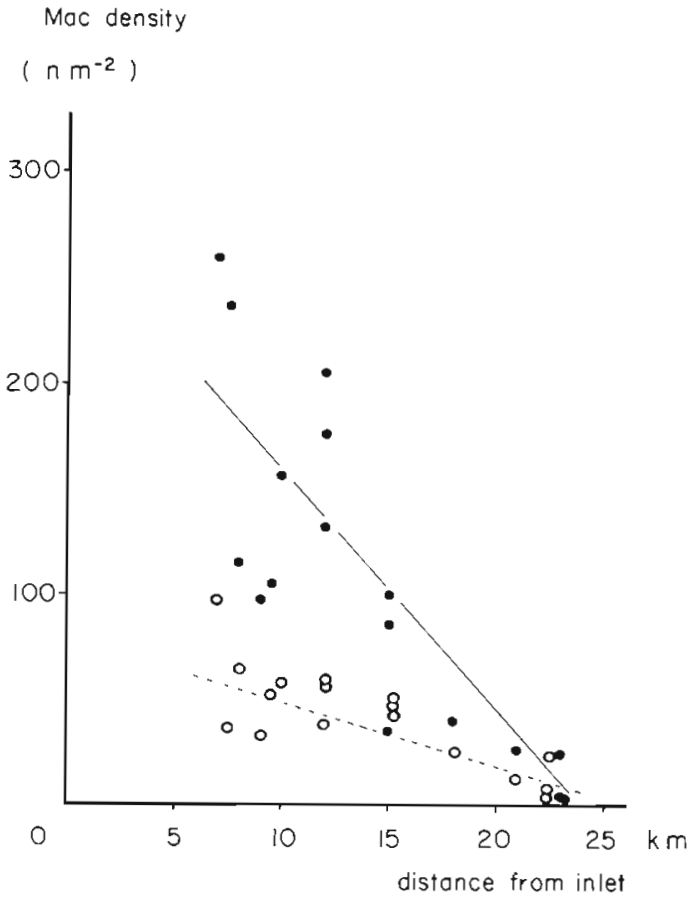

Fig. 5. Macoma balthica. Mean numbers per $\mathrm{m}^{2}$ of ( $\bullet$ juveniles (ca 1 yr old) and (O) adults caught by grab sampling at 17 stations at various distances $(\mathrm{km})$ from the tidal inlet between Terschelling and Ameland (see Fig. 1a). Mean numbers of 9 annual samples of $2 \mathrm{~m}^{2}$ each taken in spring between 1973 and 1982

With increasing distance from the tidal inlet, the size of the juveniles decreased (Fig. 6). They were measured at the year mark to obtain their length at the start of the growing season and at which size the great majority of them would have arrived in the sampling area. Samples taken in spring 1980 of the abundant 1979 year class were used. The negative correlation between distance and mean length is statistically significant ( $p<0.001, r=-0.92$, Spearman rank test).

In conclusion: the above data confirm all 3 predictions. The majority of the Macoma balthica living in the North Sea off Terschelling will have reached this area by migration from the Wadden Sea in winter by tidalcurrent transport.

\section{DISCUSSION}

Thread drifting in juvenile Macoma balthica results in massive displacements in winter when the turbulent tidal currents serve as the transporting agent. Because numbers passing in ebb currents were at all places and all times higher than during flood, net transport is directed from the coastal and estuarine Wadden Sea towards the North Sea.

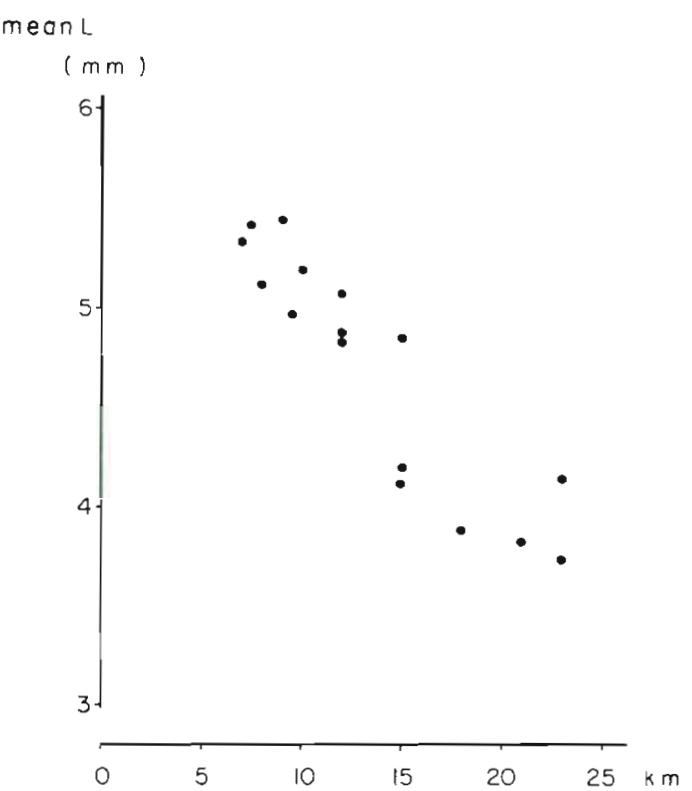

Fig. 6. Macoma balthica. Mean lengths at the year mark of shells of the 1979 year class caught in April 1980 by grab sampling at 16 stations off Terschelling located at various distances $(\mathrm{km})$ from the tidal inlet between Terschelling and Ameland. Per station generally 50 shells were measured, but at 1 station only 11 were caught and at 1 of the 17 stations none

This net transport results in real dispersal and eventual establishment of Macoma balthica in the coastal North Sea area outside the barrier islands. In this area, settlement occurs, if at all, in low densities during the season of metamorphosis from larvae to bottom stages. During this spring-summer season of primary settlement high densities of spat only arise at high coastal tidal flats. Thus a very different habitat is colonized as a consequence of the winter migration. That this habitat is suitable is shown by the distribution patterns established immediately after migration which persist for years (compare solid and broken line in Fig. 5).

Apart from the extension of the area of distribution, other functional aspects appear to be involved. Growth rates are higher in the newly occupied areas, such as low tidal flats (Beukema et al. 1977) and subtidal areas (pers. obs.), than on the high tidal flats from where the juveniles originate. This is true for length, weight of soft parts (unpubl.), and shell weight (Fig. 1 of Beukema 1980). Annual rates of survival also appear to be generally lower on high than on low tidal flats (Van Moorsel 1979, pers. obs.). Parasite infection appears to be more frequent on high than on low tidal flats (Hulscher 1973) or in the subtidal (Swennen \& Ching 1974). Thus, for adult Macoma balthica the areas of secondary settlement appear to be more favourable than the areas of metamorphosis. 
There is only a low rate of successful primary settlement in the subtidal and on low tidal flats, where nearly all adult Macoma balthica originate from secondary settlement. With respect to 2 environmental factors the lower areas are obviously less suitable than high tidal flats for the small (ca $0.2 \mathrm{~mm}$ ) justmetamorphosed postlarvae. The first is the relatively high density in low areas of epifaunal predators such as shore crabs, brown shrimps and flat fishes, whereas the highest tidal flats are a refuge from such predators (Reise 1985, pers. obs.). The second factor is the difference in sediment characteristics and exposure: the just-metamorphosed postlarva is hardly larger than a sand grain of median size in most areas of secondary settlement. Moreover, sand is highly mobile in such exposed areas owing to the action of wind- and tidedriven currents. Sediment characteristics are quite different on the high and sheltered tidal flats where primary spat fall is intense. In these quiet areas, nearly all sediment particles are smaller than a justmetamorphosed larva and most particles are less than half of this size. For small spat, life in such areas would leave more time for feeding and requires less energy for maintenance

The migration in the Wadden Sea described here may also occur in other populations of Macoma balthica. The following indications were found in the literature: in Hudson Bay, Canada Martini \& Morrison (1987) and in The Wash, England Reading (1979) observed changes in downward size distribution; on the east coast of North America, Dauer et al. (1982) regularly observed spat in plankton in winter and spring; in the Baltic, Segerstrale (1927) assumed that all $M$. balthica in the deeper parts had originated from shallow areas; in the former Grevelingen estuary Wolff \& de Wolf (1977) and in the eastern part of the Dutch Wadden Sea, Kleef \& Essink (1982) observed a redistribution of $M$. balthica spat in winter.

The migration of Macoma balthica is of clear importance for the coastal offshore ecosystem of the North Sea. Though the amounts imported are not very high (in the order of $1000 \mathrm{~kg}$ of organic $M$. balthica material per year for the Marsdiep tidal inlet and about 10000 $\mathrm{kg}$ for the entire Wadden Sea; in the order of $0.1 \mathrm{~g}$ $\mathrm{m}^{-2} \mathrm{yr}^{-1}$ of such organic material arrived at the bottom in the sampling area off Terschelling), the subsequent production of organic matter may be estimated to account for annual amounts in the order of several grams per $\mathrm{m}^{2}$ in the colonized area (all estimates in ashfree dry weight). After a severe winter, when most of the fauna had succumbed in this area (as observed in early 1979; Beukema et al. 1988), M. balthica became the dominant species and accounted for more than half of the macrozoobenthic biomass and production and for nearly all of the mollusc biomass. Ziegelmeier (1978) observed a similar dominance of $M$. balthica in the eastern part of the German Bight after the severe winter of $1962-63$

\section{LITERATURE CITED}

Baggerman, B. (1953). Spatfall and transport of Cardium edule L. Archs néerl. Zool. 10: 315-342

Bayne, B. L. (1964). Primary and secondary settlement in Mytilus edulis L. (Mollusca). J. Anim. Ecol. 33: 513-523

Beukema, J. J. (1973). Migration and secondary spatfall of Macoma balthica (L.) in the western part of the Wadden Sea. Neth. J. Zool. 23: 356-357

Beukema, J. J. (1974a). The efficiency of the van Veen grab compared with the Reineck box sampler. J. Cons. int. Explor Mer 35: 319-327

Beukema, J. J. (1974b). Seasonal changes in the biomass of the macrobenthos of a tidal flat area in the Dutch Wadden Sea. Neth. J. Sea Res. 8: 94-107

Beukema, J. J. (1980). Calcimass and carbonate production by molluscs on the tidal flats in the Dutch Wadden Sea. I. The tellinid bivalve Macoma balthica. Neth. J. Sea Res. 14 323-338

Beukema, J. J., Cadée, G. C., Jansen, J. J. M. (1977). Variability of growth rate of Macoma balthica (L.) in the Wadden Sea in relation to availability of food. In: Keegan, B. F., Ceidigh, P. O., Boaden, P. J. S. (eds) Biology of benthic organisms. Pergamon Press, Oxford, p. 69-77

Beukema, J. J., de Bruin, W., Jansen, J. J. M. (1978). Biomass and species richness of the macrobenthic animals living on the tidal flats of the Dutch Wadden Sea: long-term changes during a period with mild winters. Neth. J. Sea Res. 12: 58-77

Beukema, J. J., Dörjes, J., Essink, K. (1988). Latitudinal differences in survival during a severe winter in macrozoobenthic species sensitive to low temperature. Senckenb maritima (in press)

Dauer, D. M., Ewing, R. M., Sourbeer, J W., Harlan, W. T., Stokes, T L. Jr (1982). Nocturnal movements of the macrobenthos of the Lafayette River, Virginia. Int. Revue ges Hydrobiol. 67: 761-775

Dulk, P. den, van der Velde, A. (1987). Draadvorming bij het nonnetje (Macoma balthica L.). Report, NIOZ, Texel

Hulscher, J. B. (1973). Burying-depth and trematode infection in Macoma balthica. Neth. J. Sea Res. 6: 141-156

Kleef, H. L., Essink, K. (1982). Onder zoek naar redistributie van Macoma balthica broed in het voorjaar in de Bocht van Watum (Eems-Dollard estuarium). Rapport v. RIZA, Groningen, nr. BI-MV 82-03: 1-3

Lane, D. J. W., Beaumont, A. R., Hunter, J. R. (1985). Byssus drifting and the drifting threads of the young post-larval mussel Mytilus edulis. Mar. Biol. 84: 301-308

Martini, I. P., Morrison, R. I. G. (1987). Regional distribution of Macoma balthica and Hydrobia minuta on the subarctic coasts of Hudson Bay and James Bay, Ontario, Canada. Estuar. coast. Shelf Sci. 24: 47-68

Moorsel, G. W. N. M. van (1979). Overleving van Macoma balthica op het Balgzand. Int. Versl. NIOZ, Texel 1979-1:146

Prezant, R. S., Chalermwat, K. (1984). Flotation of the bivalve Corbicula fluminea as a means of dispersal. Science 225 1491-1493

Reading, C. J. (1979). Changes in the downshore distribution of Macoma balthica (L.) in relation to shell length. Estuar. coast. mar. Sci. 8: 1-13 
Reise, K. (1985). Tidal flat ecology. Springer-Verlag, Heidelberg

Segerstrale, S. G. (1927). Kommt bei Tellina baltica eine Wanderung aus der Uferzone vor? Soc. Scient. Fenn., Comm. Biol. 2, 11: 1-8

Sigurdsson, J. B., Titman, C. W., Davies, P. A. (1976). The dispersal of young post-larval bivalve molluscs by byssus threads. Nature, Lond. 262: 386-387

Swennen, C. (1955). Over verplaatsingen bij schelpdieren en speciaal zwemmende Macoma's. Zeepaard 15: 7-9

Swennen, C., Ching, H. L. (1974). Observations on the trematode Parvatrema affinis, causative agent of crawling tracks of Macoma balthica. Neth. J. Sea Res. 8: 108-115

Vlas, J. de (1973). Migratie via getijstromen van jonge nonne-

This article was submitted to the editor tjes, Macoma balthica L., op en rond het Balgzand. Int. Verslag NIOZ, Texel 1973-14:1-30

Williams, A. B., Porter, H. J. (1971). A ten-year study of meroplankton in North Carolina estuaries: occurrence of postmetamorphal bivalves. Chesapeake Sci. 12: 26-32

Wolff, W. J., de Wolf, L. (1977). Biomass and production of zoobenthos in the Grevelingen estuary, the Netherlands. Estuar. coast. mar. Sci. 5: 1-24

Yankson, K. (1986). Observations on byssus systems in the spat of Cerastoderma glaucum and $C$. edule. J. mar. biol. Ass. U.K. 66: 277-292

Ziegelmeier, E. (1978). Macrobenthos investigations in the eastern part of the German Bight from 1950 to 1974. Rapp. P.-v. Réun. Cons. int. Explor. Mer 172: 432-444

Manuscript received: September 27, 1988

Revised version accepted: December 16, 1988 